\title{
Timothy May, Dashdondog Bayarsaikhan, Christopher P. Atwood (eds.). New Approaches to Ilkhanid History
}

\section{Simon Berger}

\section{(2) OpenEdition}

1 Journals

\section{Édition électronique}

URL : https://journals.openedition.org/abstractairanica/53836

DOI : 10.4000/abstractairanica.53836

ISSN : 1961-960X

Éditeur :

CNRS (UMR 7528 Mondes iraniens et indiens), Éditions de l'IFRI

Référence électronique

Simon Berger, «Timothy May, Dashdondog Bayarsaikhan, Christopher P. Atwood (eds.). New Approaches to I/khanid History ", Abstracta Iranica [En ligne], Volume 42-43| 2021, document 39, mis en ligne le 30 décembre 2021, consulté le 13 décembre 2022. URL : http://journals.openedition.org/ abstractairanica/53836 ; DOI : https://doi.org/10.4000/abstractairanica.53836

Ce document a été généré automatiquement le 13 décembre 2022.

Tous droits réservés 


\title{
Timothy May, Dashdondog Bayarsaikhan, Christopher P. Atwood (eds.). New Approaches to Ilkhanid History
}

\author{
Simon Berger
}

\section{RÉFÉRENCE}

Timothy May, Dashdondog Bayarsaikhan, Christopher P. Atwood (eds.). New Approaches to Ilkhanid History. Leyde : Brill, 2020, i-xxi, 440 p., ISBN: 978-90-04-43739-5

1 Cet ouvrage collectif est issu du colloque "New Approaches to Ilkhanid History », qui s'est tenu à Oulan-Bator à l'été 2014. Celui-ci avait déjà donné lieu à une première publication en mongol (Dashdondog Bayarsaikhan, Christopher P. Atwood, Il-Xaadyn sudlal šinè xandlaga : ögüüllijn èmxètgèl, Oulan-Bator, 2016). Le présent volume réunit une partie des communications précédemment publiées, traduites en anglais en augmentées par leurs auteurs, alors que de nouvelles contributions sont venues s'y ajouter. Ce livre contient au total quatorze études, organisées en quatre parties thématiques :

\section{1) Languages and Letters in the Ilkhanid World}

3 - A. C. S. Peacock, "Nizāàm al-Dīn al-Ișfahānī, "Chief Qadi of China and the East": an Ilkhanid Man of Letters at the Court of the Juwaynīs » (cf. le compte rendu dans ce même numéro d'A AbstIr) ;

4 - K. Shiraiwa, «Mongol Endorsement of the Islamic Institution of Pious Endowment (Waqf) as Revealed in the Waqf Document of 1272 in Arabic and Mongolian Drawn Up in Kirșehir for Nūr al-Dīn, the Son of Jaja » (cf. le compte rendu dans ce même numéro d'AbstIr) ; 
5 - C. P. Atwood, « Rashīd al-Dīn's Ghazanid Chronicle and Its Mongolian Sources » ; (cf. le compte rendu dans ce même numéro d'AbstIr) ;

6 - S. Kamola, " Salghurid History in the Jāmi‘ al-Tawārìkh: a Preliminary Exploration of Its Composition and Transmission » (cf. le compte rendu dans ce même numéro d'AbstIr) ;

$7 \quad$ 2) Material Goods and Their Exchange in the Ilkhanid World

8 - Y. Qiu, « Background and Aftermath of Fakhr al-Dīn al-Ṭībī's Voyage: a Reexamination of the Interaction between the Ilkhanate and the Yuan at the Beginning of the Fourteenth Century »;

9 - K. Matsuda, «Comparing the Depictions of the Mongol Courts Created in the Yuan and the Ilkhanate » (cf. le compte rendu dans ce même numéro d'AbstIr) ;

10 - J. Kolbas, «A Dirham for your Drinking Cup: Calculating Monetary Value » (cf. le compte rendu dans ce même numéro d'AbstIr) ;

11 3) The Ilkhans in a Middle Eastern World

12 - R. Amitai, «Political legitimation in the Ilkhanate: More Thoughts on the Mongol Imperial Ideology, the Introduction of Muslim Justifications, and the revival of Iranian Ideals » (cf. le compte rendu dans ce même numéro d' AbstIr) ;

13 - N. O. Arom, «Arrowheads of Hülegü Khan: Envoys and Diplomacy in His Invasion of the Middle East, 1255-1262 » (cf. le compte rendu dans ce même numéro d'AbstIr) ;

14 - T. May, « The Ilkhanate and Afghanistan » (cf. le compte rendu dans ce même numéro d'AbstIr) ;

15 - M. Hope, "The Atābaks in the Mongol Empire and the Ilkhanate of Iran " (602-736/1206-1335);

16 4) The Ilkhans in a World of Christendoms

17 - P. G. Borbone, "The History of Mar Yahballaha and Rabban Sawma as a Source for Ilkhanid History ";

18 - D. Bayarsaikhan, "Armenian Hagiography on the Ilkhans » (cf. le compte rendu dans ce même numéro d'AbstIr) ;

19 - D. Korobeinikov, « The Ilkhans in the Byzantine Sources » (cf. le compte rendu dans ce même numéro d'AbstIr) ;

20 Ces contributions, qui sont précédées par une préface et une introduction et suivies d'un index général, sont recensées individuellement dans ce volume.

\section{AUTEURS}

\section{SIMON BERGER}

Doctorant EHESS, CETOBAC, Paris 